\title{
A METHOD FOR CELLULOSE DETERMINATION
}

\author{
L. Paloheimo, Eine Herkola, and M.-L. Kero \\ Department of Animal Husbandry, University of Helsinki
}

Received December 29, 1961

The developing of a method for determination of a certain substance occurring in plant or animal materials implies the definition of the substance in question as well as the accessibility of pure preparation of it. As for polymeric macromolecular structures like cellulose, the definition remains more or less vague and the second condition likewise is difficult to attain.

According to OtT and Tennent $(9$, p. 6) the ideal cellulose is a linear polymer composed of individual anhydroglucose units (also called glucopyranose units) linked at the 1 and 4 positions through glucosidic bonds with the beta configuration. The number of the anhydroglucose units range from about 100 to 10000 or more. The above authors point out that "this ideal cellulose is the compound which actual fractions approach more closely, the more carefully they are isolated and purified". Cottonseed fibres are made up almost exclusively, up to $96 \%$ of the dry matter, of this substance and thus afford a rather pure natural preparation of cellulose. By boiling $100 \mathrm{~g}$ of hand-cleaned raw cotton in a $1 \% \mathrm{NaOH}$ solution with complete exclusion of air, about $96 \mathrm{~g}$ of a preparation is obtained of which $99.8 \%$ is pure cellulose. Carefully produced cellulose preparations of other plants and plant organs exhibit chemical properties identical with those of cotton cellulose. This fact, however, does not prove the identity of its form occurring in plant tissues. The possible existence of compounds of cellulose with other cell wall polysaccharides and lignin has not been definitely denied $(17$, p. 26$)$, and Husemann and Schulz (ref. 14, p. 43, 44) maintain that in cellulose molecules the anhydroglucose chain is not continuous but intercalated by other sugar anhydrides, the main sequences containing $100-500$ anhydroclucose units. Such "foreign" compounds can appear also in the cellulose preparations. 
In the analysis of plant products it is evidently impossible and even purposeless to determine the eventual lignocellulose or cellulose-hemicellulose compounds. A better way is to determine the mideal cellulosen irrespectively of its mode of existence in the plant cell walls. Lignin and hemicelluloses are determined separately. In the following description only those methods are mentioned which are intended for and useful to the determination of the ideal cellulose.

The reliability of the different methods has been systematically controlled mainly for woods but also for cereal straw and certain fibre materials like cotton, hemp, and jute. In the case of human and animal foods, the cellulose determination methods have usually been applied without closer examination of their reliability.

The classical method for the estimation of cellulose is that of Cross and Bevan, first published 1903. The main principle of the method is alternate chlorination and sodium sulfite extraction. Before the first chlorination the sample is boiled with $1 \% \mathrm{NaOH}$ solution (3, p. 352). The chlorine reacts with lignin to form substitution and oxidation products which are soluble in boiling sodium sulfite solution (1, p. 1148). During the chlorination $\mathrm{HCl}$ is formed. Later investigators have modified the original method.

In the determination of Cross and Bevan cellulose in wood according to TAPPI Standard (12, T $17 \mathrm{~m}-46)$, the pretreatment with $\mathrm{NaOH}$ solution is omitted. Before the first chlorination the sample is extracted with ethanol-benzene and washed with hot water. After each chlorination the material is washed with water, $3 \%$ $\mathrm{SO}_{2}$ solution, water, $2 \% \mathrm{Na}_{2} \mathrm{SO}_{4}$ solution, and water. Excessively long chlorination periods are to be avoided because the $\mathrm{HCl}$ formed hydrolyzes the cellulose. According to Browning (1, p. 1152) the Cross and Bevan cellulose obtained by different modifications of the method contains only a few tenths of a per cent lignin but considerable quantities of xylan and mannan. In order to obtain the percentage of the true cellulose, different corrections are recommended. Also some hydrolysis and oxidation products of cellulose are formed during the isolation treatments. A portion of these become washed out from the preparation.

In KüRSCHNER's method a 1-g sample is refluxed for 1 hour with three successive $25-\mathrm{ml}$ portions of $20 \%$ by volume conc. nitric acid in ethanol (ref. 12, p. 115). A modified method (ref. 1, p. 1154) employs 1 volume of conc. nitric acid in 2 volumes of methanol. It is claimed that all of the lignin and about $3 / 4$ of the pentosans are removed. The corrected values are identical with the corrected values obtained by the chlorination method (l.c.).

WisE et al. observed that wood is delignified by treatment with monoethanolamine at just below the boiling point $\left(168^{\circ} \mathrm{C}\right)$ (ref. 1, p. 1154). This observation has been used as basis for a cellulose determination method. The crude cellulose obtained contains $0.2-1.1 \%$ lignin and $10-32 \%$ pentosans.

In the method of Norman and Jenkins (ref. 1, p. 1156) the material is extracted with methanol-benzene, boiled with $3 \% \mathrm{Na}_{2} \mathrm{SO}_{3}$ and treated with aqueous solution of sodium hypochlorite. The treatments with sulfite and hypochlorite are repeated several times. The crude cellulose contains considerable amounts of pentosans and contains $1-3 \%$ lignin. This method, which has also been applied to forage crops, is not intended for determining true cellulose. It is, however, related here because 
it is analogous with the above-described methods and can be used, with pentosan and lignin corrections, even for determining true cellulose. MATRONE et al. (6, p. 306) have modified the original method in order to make it less time-consuming.

Kiesel and Semiganowsky (5, p. 333) have developed a cellulose determination method on a quite different basis than the above-mentioned authors. In their method the cellulose is hydrolysed by a treatment with $80 \%$ sulphuric acid at room temperature and subsequent boiling in diluted acid. Before these hydrolysis treatments the matter to be analysed is boiled with $2 \% \mathrm{HCl}$ solution and extracted with ethanol and ether. The reducing sugar is determined from the obtained solution by Bertrand's method, and the percentage of cellulose is calculated by using the coefficient 0.9 .

In Waksman's and Steven's (16, p. 167) fractionation of vegetable products, cellulose is determined principally in the same way as in the above method. The final hydrolysing to glucose is performed at $120^{\circ} \mathrm{C}$. According to these authors the results are $4-5 \%$ lower than the actual cellulose content in the plant material. M.-L. SALO (11, p. 32) in her fractionation system also uses a similar principle.

\section{The method}

The principle. The methods for cellulose determination, excepting those in which the cellulose is hydrolyzed and determined as glucose anhydride, originate from the attempts to obtain pure cellulose preparations. Therefore it has been attempted to remove non-cellulosic components as completely as possible. The lignin is destroyed by chlorination or oxidation. However, the residues obtained have appeared to contain impurities in such amounts that different corrections are needed. It is also questionable if the cellulose remains intact.

In developing our method we have disregarded the complete removal of noncellulosic components. Instead, we are satisfied with obtaining a crude cellulose preparation which still contains appreciable amounts of pentosans together with some protein and lignin. By use of due corrections, however, the amount of the true cellulose is obtained.

General features of the method. The sample is extracted with ethanol solutions for removing sugars, fructosans, ${ }^{1}$ and chlorophyll. Then follows a treatment with $3 \mathrm{~N} \mathrm{NaOH}$-solution at $100^{\circ} \mathrm{C}$ and filtration through asbestos. The crude cellulose is determined as the loss after incineration. Two other preparations are made for determinations of pentosans and crude lignin. No protein correction is needed because the crude lignin seems to contain all protein of the preparation. The amount of the true cellulose is obtained by subtracting the amounts of pentosans and crude lignin from the crude cellulose. If the matter to be analyzed contains considerably fat, it is advisable to extract it with benzene-ethanol before the $\mathrm{NaOH}$ treatment. If it contains much starch, the preparation obtained by $\mathrm{NaOH}$-treatment

${ }^{1}$ In boiling alkali solution fructose is converted into insoluble products of secondary condensation. 
should be boiled with $0.05 \mathrm{~N} \mathrm{HCl}$ solution. This acid treatment must follow the alkaline treatment because one part of the formed hydrocellulose dissolves in boiling with the $\mathrm{NaOH}$ solution.

Details of the analysis. The dried material is ground to pass a $1 \mathrm{~mm}$ sieve. Three 2-g samples are weighed for the cellulose determination and one $2-3 \mathrm{~g}$ sample for moisture determination. Each of the 2-g samples is put in an envelope made of Whatman No. 1 filter paper, and the envelope is put in a Soxhlet apparatus. The middle cylinder of the apparatus is filled with boiling $50 \%$ ethylene solution to the bend of the siphon and thermoisolated with paper or cloth. In our apparatus the amount of alcohol solution was $90 \mathrm{ml}$. The same volume of absolute alcohol is put in the extraction flask. After 1 hour the heating is connected and the extraction is continued for 8 hours.

The dried extracted sample is transferred into a $130-140 \mathrm{ml}$ pressure bottle. $120 \mathrm{ml} 3 \mathrm{~N} \mathrm{NaOH}$ solution is heated to boiling in a beaker. $10-20 \mathrm{ml}$ of this solution is put into the bottle and throughly mixed with the sample. Then the rest of the solution is transferred into the bottle. The bottle is provided with a rubber stopper and put into a boiling water bath where it is shaken by a shaking machine for 2 hours. As the air space in the bottle is very small, the oxidation of cellulose is practically avoided. Then the mixture is filtered through asbestos in a Gooch crucible. The residue is washed thoroughly with boiling water, with cold $0.1 \mathrm{~N} \mathrm{HCl}$ solution and again with boiling water. The crucible with the contents is dried at $100-105^{\circ} \mathrm{C}$ and the loss after incineration is determined. The result obtained gives the amount of crude cellulose. If the material contains starch, the residue in the Gooch crucible should be boiled $1 / 2$ hour with $400 \mathrm{ml}$ of $0.05 \mathrm{~N} \mathrm{HCl}$ solution, then filtered etc.

Another sample is similarly treated, but instead of being incinerated, it is used for crude lignin determination. It is transferred into a $100 \mathrm{ml}$ beaker and throughly moistened with $5 \mathrm{ml}$ cold water. $45 \mathrm{ml}$ cold $\left(0^{\circ} \mathrm{C}\right) 77 \% \mathrm{H}_{2} \mathrm{SO}_{4}$ solution is added in two portions and mixed. The beaker is placed for 3 hours in $18^{\circ}-20^{\circ} \mathrm{C}$ water bath and stirred at $1 / 2$ hour intervals. Then it is rinsed into a beaker with a mark at $350 \mathrm{ml}$. The mixture is heated to boiling and filtered through asbestos. Tre residue is washed with boiling water and dried at $100-105^{\circ} \mathrm{C}$. The loss after incineration gives the amount of the crude lignin.

The third sample is treated like the first, but instead of being incinerated is used for pentosan determination. The determination is made according to Tollens' principle using the modification described in the Official Methods of Analysis (8, p. 376).

\section{Criticism and discussion}

It was mentioned above that the protein of the crude cellulose is not hydrolyzable by the strong acid treatment of the lignin determination and therefore practically all of it remains in the crude lignin. This circumstance is shown in Table 1 , 
Table 1. Percentage composition of crude cellulose

\begin{tabular}{|c|c|c|c|c|c|}
\hline Material analysed & $\begin{array}{c}\text { True } \\
\text { cellulose }\end{array}$ & Pentosans & $\begin{array}{l}\text { Pure } \\
\text { lignin }\end{array}$ & $\begin{array}{l}\text { Crude } \\
\text { protein }\end{array}$ & $\begin{array}{c}\text { Protein of } \\
\text { crude } \\
\text { lignin }\end{array}$ \\
\hline Spruce wood & 61.29 & 9.11 & 29.37 & 0.12 & 0.11 \\
\hline Pine & 56.90 & 11.76 & 31.12 & 0.09 & 0.13 \\
\hline Birch , & 68.27 & 7.66 & 23.75 & 0.16 & 0.16 \\
\hline Rye, leaf stage & 86.70 & 4.22 & 5.66 & 1.99 & 1.43 \\
\hline blooming & 87.30 & 4.57 & 6.86 & 0.68 & 0.59 \\
\hline straw & 86.46 & 5.37 & 7.67 & 0.35 & 0.15 \\
\hline Red clover, in bud & 73.99 & 4.50 & 14.46 & 3.90 & 3.15 \\
\hline Sugar beet tops & 78.17 & 4.88 & 9.76 & 3.90 & 3.29 \\
\hline Sedge (Carex gracilis) & 84.27 & 5.17 & 6.24 & 2.32 & 2.00 \\
\hline Peanut hulls & 43.40 & 14.78 & 38.75 & 1.60 & 1.47 \\
\hline
\end{tabular}

The authors have made a detailed investigation on the sugar anhydride composition of the crude cellulose preparations. For that purpose the preparation was first hydrolyzed by $72 \% \mathrm{H}_{2} \mathrm{SO}_{4}$ solution. After 35.5 -fold dilution with water, the hydrolysis was completed by refluxing for 6 hours. After filtration an aliquote of the filtrate was shaken with Duolite A-7 ion exchanger, whereby the solution was neutralized. After another filtration the solution is, if necessary, adjusted to $\mathrm{pH} 2-3$ with $6 \mathrm{~N} \mathrm{NaOH}$. $50 \mathrm{ml}$ of the solution were concentrated to $2 \mathrm{ml}$. This

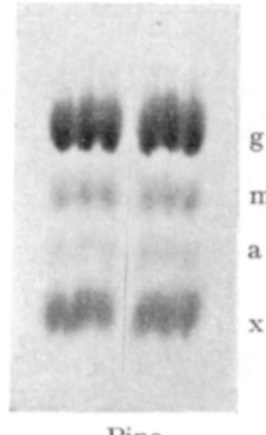

Pine

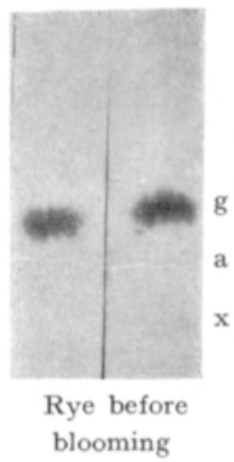

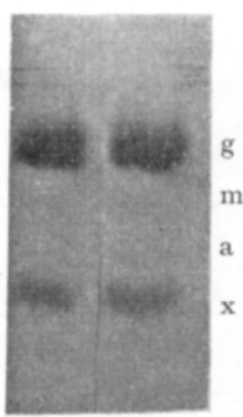

Birch

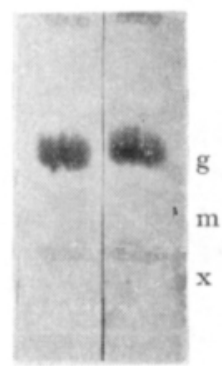

Red clover quite youug

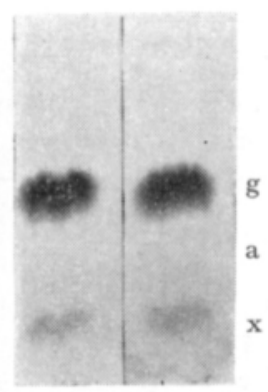

Rye straw

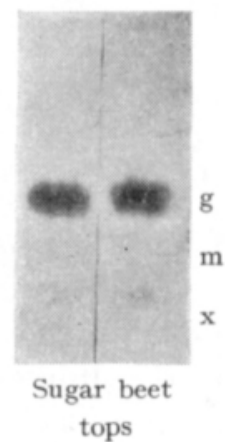

Fig. 1. Chromatograms of some crude cellulose preparations. g glucose, $m$ mannose, a arabinose, $x$ xylose. 
concentrated solution was used for a chromatographic analysis. Filter paper Whatman No. 1 was used as sorbent, and the solvent was a butanol + glacial acetic acid + water mixture 4:1:5. For the development of the chromatogram, aniline phtalate was used (aniline $930 \mathrm{mg}$, phtalic acid $1.6 \mathrm{~g}$, and butanol saturated with water $100 \mathrm{ml}$ ). Of 3 parallel sorbent strips the middle strip was not developed, and areas parallel with the corresponding coloured zones of the neighbouring strips were cut out. In addition a blind area of the middle strip was cut out for analysis. These pieces of paper were minced in small fragments and put in a test tube for microdetermination of sugar according to the method of Somogyi (13, p. 61). During the titration the test tubes were shaken vigorously several times.

Fig. 1. shows the chromatograms of some crude cellulose preparations. It is seen that the crude cellulose of pine wood contains a great deal impurities, besides pentosans also a considerable amount of mannan. The main impurity in the birch wood preparation is xylose. The other four cromatograms show less impurities. In this connection it should be remembered that the calculation of the amount of pure cellulose includes the pentosan correction. Therefore the occurrence of araban and xylan in a crude cellulose preparation does not impair the usefulness of the method.

Table 2. Components of crude cellulose ( $\%$ of the original dry matter)

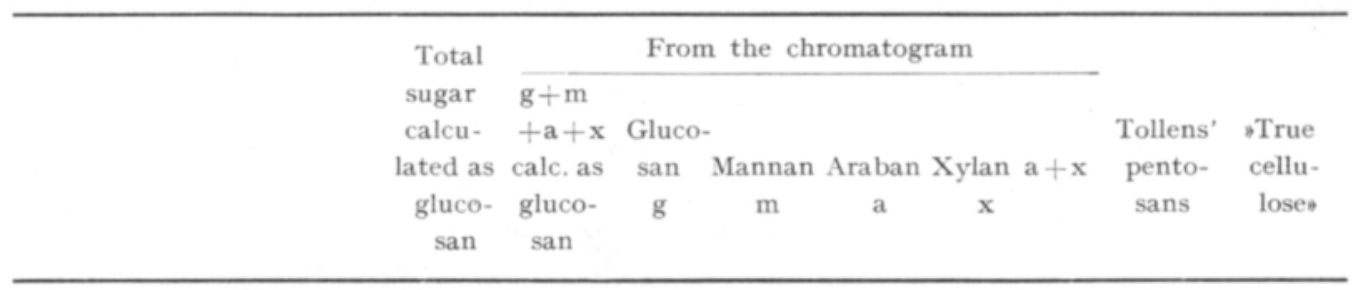

\begin{tabular}{|c|c|c|c|c|c|c|c|c|c|}
\hline Filter paper & 99.9 & & 98.4 & & & & & 0.0 & \\
\hline Cotton fibre & 100.4 & & 95.6 & & & & & 0.0 & \\
\hline Spruce wood (Pica excelsa) & 53.0 & 49.3 & 38.6 & 6.6 & 1.4 & 3.6 & 5.0 & 7.5 & 50.2 \\
\hline - (Pinus silvestris) & 48.1 & 43.9 & 34.3 & 5.9 & 0.6 & 4.0 & 4.6 & 9.1 & 43.9 \\
\hline - (Betula verrucosa) & 40.6 & 36.7 & 31.6 & 1.3 & 0.8 & 3.1 & 4.0 & 4.7 & 41.9 \\
\hline Pteris aquilina stalks & 36.4 & 36.7 & 29.8 & 4.1 & 0.0 & 3.6 & 3.6 & 6.4 & 33.9 \\
\hline Rye, leaf stage & 11.4 & 10.1 & 9.7 & 0.0 & + & 0.4 & $0.4+$ & 0.5 & 11.0 \\
\hline , before blooming & 24.3 & 23.5 & 22.2 & 0.0 & + & 1.1 & $1.1+$ & 1.1 & 23.8 \\
\hline - blooming & 28.9 & 28.6 & 26.5 & 0.0 & 0.9 & 1.2 & 2.1 & 1.5 & 28.3 \\
\hline straw & 34.9 & 35.4 & 32.7 & 0.0 & 0.6 & 2.0 & 2.6 & 2.1 & 34.7 \\
\hline Timothy, leaf stage & 14.3 & 13.6 & 12.8 & 0.0 & + & 0.7 & $0.7+$ & 0.7 & 14.0 \\
\hline blooming & 25.7 & 25.4 & 23.3 & 0.0 & 0.7 & 1.2 & 1.9 & 1.3 & 23.2 \\
\hline Red clover, young & 7.7 & 7.0 & 6.7 & 0.2 & 0.0 & 0.2 & 0.2 & 0.4 & 8.5 \\
\hline Sugar beet tops & 6.0 & 5.6 & 5.5 & + & 0.0 & 0.1 & $0.1+$ & 0.4 & 6.5 \\
\hline
\end{tabular}

Table 2 shows the results obtained by the sugar analyses from the different zone areas. The table also shows the total amount of pentosans in the crude cellulose determined by Tollens' method, the percentage of true cellulose, and the total amount of sugars obtained by hydrolysis of the crude cellulose and calculated as glucosan. As for the fodders shown in the table, no evident discrepancies are seen. Thus 
the figures in the two first columns are fairly well in accord. Also, the sum araban + xylan is of the same order as the total of Tollens' pentosans, and the figures for true cellulose are only slightly higher than the corresponding figures for glucosan obtained from the chromatograms. It is seen that the fodders contain no mannan, or only traces of it, in their crude cellulose. The part of the Table 2 which pertains to the different woods and Pteris aquilina stalks shows some large discrepancies. The crude cellulose of these materials contains mannan and thus the figures for the true cellulose are too high. However, if the mannan is subtracted from the true cellulose, the differences obtained are nevertheless higher than the corresponding glucosan figures. The sum of the chromatogram sugar-anhydrides for the woods is appreciably lower than the total sugar obtained by hydrolysis of the crude cellulose and calculated as glucosan. Likewise, the figures of Tollens' pentosan are much higher than the corresponding sum araban + xylan.

For the purpose of studying the solubility of cellulose in the alkali treatment used in our method, crude cellulose preparations were made of filter paper, cotton fibre, and linen cloth. The crude lignin content of these materials was correspondingly $0.0,1.35$ and $2.60 \%$ of dry matter. When these preparations were subjected to cellulose determination, the dry matter losses were about 4,3 , and $6 \%$.

In an earlier paper of this department $(10$, p. 51) the cellulose percentages of 44 different plant materials are presented. The respective determinations were made by the method in question. In another paper of this institute SALO (11, p. 32) presents some results of her cellulose determinations which were made using the hydrolysis method (see above). Some of them were made on the same materials as the analyses in the former investigation. Table 3 shows that the results correspond with each other rather well although the two methods are very different.

Table 3. Cellulose percentages obtained by the present method (a) compared with the results obtained by the hydrolysis method of Salo (b)

\begin{tabular}{lrr} 
& a & \multicolumn{1}{c}{ b } \\
Timothy, blooming & 26.6 & 27.9 \\
Rye straw & 34.7 & 35.9 \\
Red clover, young & 8.5 & 9.2 \\
Sugar beet tops & 14.9 & 14.9 \\
Chickweed (Stellaria media) & 6.5 & 7.1 \\
Wheat bran & 9.2 & 11.1 \\
& 7.6 & 8.5
\end{tabular}

It is difficult to find from scientific or technical literature any trustworthy information on the cellulose content of natural plant materials. The most useful figures the authors have found for materials other than woods are those presented by SALO (1. c.). As for the woods, the cellulose figures usually pertain to preparations which still contain pentosans and hexosans other than cellulose. Even figures claimed to give the amount of pentosan-free cellulose have not been subjected to a mannan correction. In the tables presented by BROWNING and ISENBERG (2, p. 1267-1269) American hardwoods contain 49-64\% cellulose and soft woods 44-58\%. 
According to different authors Nikitin (7, p. 352, 353) gives percentages 33-56 for the hardwoods of USSR and for the softwoods 41-54. According to different workers (ref. 4, p. 351) German hardwoods contain 40-49\% pentosan-free cellulose and softwoods 41-44\%. HäGGLUND (4, p. 129-131) has tried to estimate the true cellulose content of spruce wood (Picea excelsa). After corrections for mannan, galactan and pentosans he arrived at figures between 42.3 and $43.2 \%$ "of the weight of the wood" (evidently of the dry matter). Staudinger and Husemann (ref. 4, p. 132) using another method, obtained cellulose percentages of $38-50$ for hardwoods, 41-42 for Picea excelsa, and 40 for Pinus silvestris.

\section{Summary and coclusions}

The usual metods for cellulose determinations, excepting those in which the material is decomposed by total hydrolysis, are principally methods for producing cellulose preparations. In these the non-cellulosic compounds are tried to be removed as thoroughly as possible without decomposing the cellulose. However, the preparations obtained still contain different non-cellulosic components for which corrections must be made. In the method proposed by the authors a crude cellulose preparation is produced by a relatively mild treatment, and corrections are made for crude lignin and pentosans. The main feature in producing the crude cellulose preparation is shaking the samples with $3 \mathrm{~N} \mathrm{NaOH}$ solution in pressure bottles in a boiling water bath.

The method appears to give realiable results for fodder materials. For woods the results are evidently too high, especially due to mannan in the crude cellulose.

\section{REFE R E C E S}

(1) Browning, B. L. 1952. The isolation of cellulose preparations and the determination of cellulose. Wood Chemistry, edited by Wise and Jahn, 2nd ed., vol. 2. New York. 1138-1158.

(2) Browning B. L. \& Isenberg, I. H. 1952. Analytical data and their significance. ibid. $1259-1277$.

(3) Dorḱe, Charles. 1950. The Methods of Cellulose Chemistry. 2nd ed. London. $1-543$.

(4) Hägglund, ERIK. 1951. Chemistry of wood. New York. 1-631.

(5) Kiesel, A. \& Semiganowsky, N. 1927. Cellulose-Bestimmung durch quantitative Verzuckerung. Berichte deutsch. chem. Ges, 60: 333-338.

(6) Matrone, G. \& Ellis, G. H. \& Maynard, L. A. 1946. A modified Norman-Jenkins method for the determination of cellulose and its use in the evalution of feedstuffs. J. Animal. Sci. 5: $306-312$.

(7) Nıkıтın, N. I. 1955. Die Chemie des Holzes. Berlin. 1-569.

(8) Official Methods of Analysis of the Ass. Off. Agric. Chemists. Washington D. C., 8th ed. 1955: $1-1008$.

(9) Otт, Emil \& Tennent, H. G. 1954. Cellulose and Cellulose Derivatives I, edited by Ott \& Spurlin \& Graffin. New York and London. 1-8.

(10) Paloheimo, L. \& Vainio, K. A. \& Kero, M.-L. \& Herkol., Eine. 1960. Analysis of plant products in greater detail. J. Sci. Agric. Soc. Finland. 33: 51-56.

(11) Salo, M.-L. 1961. Determination of carbohydrates in animal foods as seven fractions. Ibid.: $32-38$.

(12) Schwalbe, C. G. \& Sieber, R. 1931. Die chemische Betriebskontrolle in der Zellstoff- und PapierIndustrie. Berlin. 1-547. 
(13) Somogyi, M. 1945. A new reagent for the determination of sugars. J. Biol. Chem. 160:61-68.

(14) Staudinger, Hermann. 1947. Makromolekulare Chemie und Biologie. Basel 1-160.

(15) TAPPI $=$ Technical Association of the Pulp and Paper Industry. Testing Methods, Recommended Practices, Spesifications. 1946. New York. T $17 \mathrm{~m}-46$.

(16) Waksman, S. A. \& Stevens, K. R. A system of Proximate Chemical Analysis of Plant Materials. Ind. and Eng. Chemistry. Analytical Ed. 2: 167-173.

(17) WARD, Kyle, Jr. 1954. Cellulose and Cellulose Derivatives I, edited by Ott \& Spurlin \& Graffin. New York and London. 9-27.

S E L OST U S:

\title{
MENETELMÄ SELLULOOSAN MÄÄRITTÄMISEKSI
}

\author{
L. Palohetmo, Eine Herkola ja M.-L. Kero \\ Kotieläintieteen laitos, Helsingin Yliopisto
}

Yleisimmin käytetyt selluloosanmääritysmenetelmät ovat kehittyneet menetelmistä, joiden tarkoituksena on mahdollisimman puhtaiden ja muuttumattomien selluloosapreparaattien valmistaminen. On kuitenkin osoittautunut, että täten saadaan valmisteita, jotka vielä sisältävăt ligniniä ja pentosaaneja sekä heksosaaneja, jotka eivät ole selluloosaa. Valmisteet ovat siis raakaselluloosaa, jolle on vielä tehtãvä ainakin ligniini- ja pentosaanikorjaus. Kirjoittajan kehittämässä menetelmässä on raakaselluloosan valmistamisessa käytetty varsin lievää käsittelyä, välittämättä siitä, että korjaukset tulevat suuriksi. Tällainen menettely katsotaan tarkoituksenmukaiseksi, koska korjaukset joka tapauksessa ovat välttämättömät. Menetelmä on seuraavanlainen.

$2 \mathrm{~g}$ hienoksi jauhettua näytettä uutetaan ensin kuumalla 50-prosenttisella ja sen jälkeen väkevämmällä alkoholilla. Sitten näyte siirretään painepulloon, johon kaadetaan 120 ml 3-normaalista kuumaa $\mathrm{NaOH}$-liuosta. Huiskutetaan 2 tuntia kiehuvassa vesihauteessa. Siivilöidäån asbestin läpi, pestään kiehuvalla vedellä, kylmällä 0.1-normaalisella $\mathrm{HCl}$-liuoksella sekä uudestaan kiehuvalla vedellä. Kuivatetaan ja määritetäăn hehkutuskevennys eli raakaselluloosa. Toinen näyte käsitellään kuivatusvaiheeseen asti samalla tavalla kuin edellinen. Saadusta preparaatista tehdään raakaligniinimääritys. Raakaligniiniin sisältyy käytännöllisesti katsoen kaikki raakaselluloosan proteiini. Kolmannesta preparaatista tehdäån pentosaanimääritys. Kun raakaselluloosasta văhennetäăn raakaligniini ja pentosaanit, saadaan puhdasselluloosa. Jos tutkittava aines sisältää tärkkelystä, on ensimmäisen näytteen käsittelyä siivilöimisen jälkeen jatkettava keittämällä jäännös 0.05-normaalisessa $\mathrm{HCl}$-liuoksessa.

Raakaselluloosapreparaatteja tutkittaessa kåvi ilmi, että kuusi-, mänty- ja koivupuusta saadut preparaatit sisältåvät mannaania, ja koska menetelmään ei sisälly mannaanikorjausta, saadaan sanotuista materiaaleista liian korkeita puhdasselluloosa-arvoja. Sen sijaan näyttää siltä, että ehdotettu menetelmä sopii hyvin rehukasvien tutkimiseen. 